

\title{
Different soil media for free-range laying hens
}

Evangelia N. Sossidou

\section{To cite this version:}

Evangelia N. Sossidou. Different soil media for free-range laying hens. British Poultry Science, 2008, 49 (04), pp.390-395. 10.1080/00071660802159041 . hal-00545336

\section{HAL Id: hal-00545336 \\ https://hal.science/hal-00545336}

Submitted on 10 Dec 2010

HAL is a multi-disciplinary open access archive for the deposit and dissemination of scientific research documents, whether they are published or not. The documents may come from teaching and research institutions in France or abroad, or from public or private research centers.
L'archive ouverte pluridisciplinaire HAL, est destinée au dépôt et à la diffusion de documents scientifiques de niveau recherche, publiés ou non, émanant des établissements d'enseignement et de recherche français ou étrangers, des laboratoires publics ou privés. 


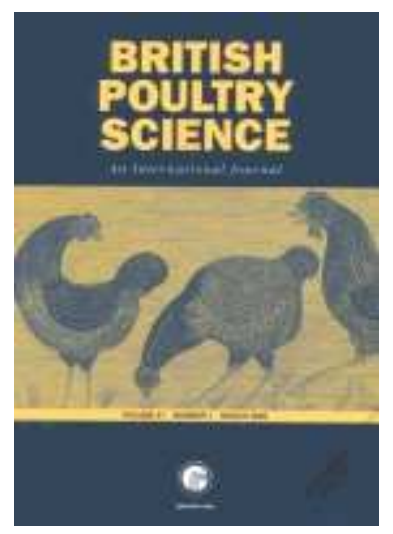

\section{Different soil media for free-range laying hens}

\begin{tabular}{|r|l|}
\hline Journal: & British Poultry Science \\
\hline Manuscript ID: & CBPS-2007-272.R1 \\
\hline Manuscript Type: & Original Manuscript \\
\hline $\begin{array}{r}\text { Date Submitted by the } \\
\text { Author: }\end{array}$ & 10 -Feb-2008 \\
\hline Komplete List of Authors: & $\begin{array}{l}\text { Sossidou, Evangelia; NATIONAL AGRICULTURAL RESEARCH } \\
\text { FOUNDATION, Animal Research Institute; NATIONAL } \\
\text { AGRICULTURAL RESEARCH FOUNDATION, Veterinary Research } \\
\text { Institute }\end{array}$ \\
\hline Beywords: & Behaviour, Free range, Environment \\
\hline
\end{tabular}

\section{s ScholarONE \\ Manuscript Central}


1

Revised ţo_END OF REFERENCES

E. N. SOSSIDOU, S .P. ROSE ${ }^{1}$, S. S .P. SILVA ${ }^{1}$, N.W. HALL ${ }^{2}$

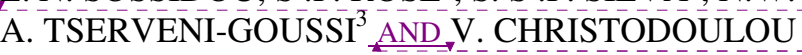

National Ágricultural Research Foundation (N.AG. RE.F.), Ánimal Research Institute, 58100 Giannitsa, Greece $T$ The National Institute of Poultry Husbandry, Harper Adams University College, Edgmond, Newport, Shropshire, England, TF10 8NB,

${ }^{2}$ Crop and Environment Research Centre, Harper Adams University College, ${ }^{3}$ A ristotle University of Thessaloniki, Faculty of Veterinary Medicine, Department of Animal Production, Ichthyology, Ecology and Protection of Environment, 54124 Thessaloniki, Greece

Running head: SOIL FOR FREE-RANGE LAYERS

Correspondence to

Accepted 19 February 2008

\section{Abstract.}

1. A replicated experiment compared bird use, soil structure, grass wear and free-moving nematode populations in 4 different soil media (recycled vegetable compost, $90 \%$ recycled vegetable compost and $10 \%$ sand, re-used topsoil and sterilised topsoil) all with established grass swards within the range area of a large free-range laying hen unit.

2. The birds initially spent a greater proportion of their time on the two topsoil swards in comparison to the two compost-based swards. However, once the whole flock of hens had prolonged access to the different swards (unfenced areas) there were no significant differences in the number of birds that frequented the different sward types.

3. The two compost-based soil media had $33 \%$ fewer nematodes per gram of dry soil compared to the two topsoil based media. However, the rate of loss of grass from the subplots was greater with the two compost-based soil media; this was probably due to the greater porosity of these types of soil media. 
There is a requirement that free-range laying hens must have continuous day-time

38 access to open-air runs that are mainly covered with vegetation (EC Council Directive

39 199/74/EC). Permanent, or semi-permanent, housing positioned within grass-sown

40 leys are often the most practical method of providing these conditions for commercial

41 laying hen flocks. A good-quality sward is important in that it provides some forage

42 for the birds at range and it avoids the area becoming muddy. Mud can stick to the

43 feet of the birds and so can transfer inside the egg laying areas. Even with a good

44 quality sward, the areas close to the entrances of houses frequently become denuded.

Parasitic worm infections are a particular problem in un-caged laying hens, and there is a high incidence in commercial free-range poultry units (Pennycott and

47 Steel, 2001). The parasites are mostly nematode worms and their incidence is higher

48 than in other loose-housing systems (Permin et al., 1999). The nematode worms

49 survive in the soil and this allows them to complete their life-cycle successfully.

50 There is a need to examine if particular soil media can be used to reduce the surviving

51 nematode population in the land surrounding free-range laying houses.

The EU Waste Management Strategy (COM(96) 399) has resulted in the 53 Landfill Directive 99/31/EC that requires $25 \%$ of household waste to be composted.

54 Composted recycled vegetable waste is now readily available and inexpensive. Not

55 only does the composting process eradicate nematodes from the vegetable material

56 (Noble and Roberts, 2004) but also the stable composted material reduces the ability

57 of nematodes, and some bacteria, to repopulate (USEPA, 1997). Vegetable waste

58 compost can be used directly, or with some modification, as a soil medium and good

59 grass swards can be established. 
1

2

3

4

5

6

7

8

9

Although the use of vegetable waste compost as a soil medium for the whole range area would be uneconomic, it is possible that the managers of commercial egg production units would consider using it to seed areas that are close to the entrances of the fixed housing and that probably have the greatest bird use. There is a need to examine whether the use of recycled vegetable compost has the potential to be used as a soil medium in the range areas and whether its use is practicable. The compost has a high water-holding capacity, so it may be that compost that includes some freedraining material, for example sand, may improve its characteristics for use in freerange units.

The objective of this study was to give preliminary information on the potential value of composted recycled vegetable waste as a soil medium for commercial free-range units.

\section{MATERIALS AND METHODS}

The experimental work was conducted at Harper Adams University College using a 4500 bird free-range egg production unit. The unit was comprised of a fixed, $\underline{\text { environmentally-controlled laying hen house that contained nest boxes, drinking and }}$ feeding equipment and $380 \mathrm{~m}^{2}$ of slatted floors. The building had a total of $9 \mathrm{~m}$ of external pop-holes, that gave the birds access to a slatted, partially-enclosed verandah area $\left(80 \mathrm{~m}^{2}\right)$. Pop-holes $(9 \mathrm{~m}$ in total) gave the birds access from the verandah to the $\underline{\text { range area. The fixed unit was sited centrally in an approximately square } 2.0 \text { hectare }}$ field. The unit had been in continuous production for the 9 years since its establishment and no amendments to the range had been made during this time. The range area used for the unit was sown to grass and the soil type was a free-draining sandy loam over sandstone. A flock of sheep was allowed to graze the range area but 
their access was restricted to more than $100 \mathrm{~m}$ from the fixed laying hen house and away from the three experimental blocks.

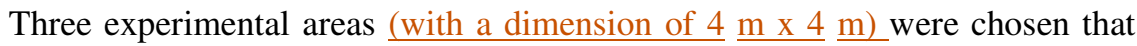
were each approximately $50 \mathrm{~m}$ from a verandah entrance to the laying hen house.

Each area was further subdivided into 4 subplots each of $4 \mathrm{~m}^{2}$ (dimensions of $4 \times 1 \underline{\mathrm{m}}$ ) and $20 \mathrm{~cm}$ of the topsoil was removed and replaced with one of the 4 soil media.

1 These media were either recycled composted vegetable waste, a mixture of $90 \%$ recycled composted vegetable waste and $10 \%$ sand, part-sterilised (steam application to a soil temperature of $86^{\circ} \mathrm{C}$ for approximately $90 \mathrm{~min}$ ) topsoil or un-sterilised topsoil obtained from the same site. The relative positions of each of the soil media subplots within the main plots were chosen using random numbers. A proprietary grass seed mixture (a mixture of grass varieties that included 35\% ryegrass and 35\% red fescue) was used to seed each of the 4 different soil media.

The grass swards were sown in March 2005 and a new 16-week-old flock of Lohmann Brown laying hens were placed in the house in the following month. The flock was managed according to the established rules for free-range egg production and the birds were fed, ad libitum, a proprietary laying hen feed. Shade and water was provided on the range at locations that were approximately $25 \mathrm{~m}$ from each of the experimental plots but feed was only provided within the fixed laying house. The experimental swards were protected from access by the birds by wire cages until September 2005 to allow correct establishment of the sward. During this time, the grass was cut mechanically and removed and grass length was maintained at $5 \mathrm{~cm}+2$ $\mathrm{cm}$ throughout this period. No fertiliser or chemical applications were made to the grass during this time.

\section{Behavioural observations}


110 Observational data of the laying hens were collected from the established plots during

111 September 2005 using the general procedures outlined by Martin and Bateson (1993).

112 The first objective was to determine the relative preference of the hens for the swards

113 grown on the 4 soil media. This work was undertaken immediately prior to allowing

114 the flock access to the experimental plots. Each plot was securely fenced and 12

115 randomly-selected birds were placed into each plot where they had free access to each

116 of the 4 subplots. Observations of the location of the birds placed within the plot were

117 taken for one hour. After this time the birds were removed and returned to the main

118 flock and a further 12 birds were randomly selected and placed in the same plot for

119 another hour of observations. Observations of bird location were therefore made on

120 two occasions (morning and afternoon) for each single main plot and observations

121 were made on each of the three main plots on following days of the same week.

122 The second objective of the behavioural observations was to determine the

123 relative use of the swards by the entire flock. The plot areas were previously unfenced 124 and the whole flock had been allowed free access to the three experimental areas as

125 well as the rest of the whole range area. Two 1-h observational periods counted the

126 numbers of birds standing on each of the 4 subplots for each open area.

127 Soil structure and grass cover measurements

Deleted: ndition

128 After the first (fenced) behavioural observations, the three plots were left unfenced in

129 ambient conditions and the free-range flock had daily access to the three plots, and

130 any other area of the range area. Six series of measurements were made at the

131 beginning of the each month, from October 2005 to March 2006 to quantify the

132 amount of grass cover remaining on the soil media in each plot. Grass score was

133 described as the proportion of grass vegetation that covered each subplot area. $\underline{\text { A }}$ 

rainfall data during the experimental period. 2006 after approximately one month of continuous use by the flock but when there

138 was still a substantial amount of grass cover on each of the subplots. The first method 139 measured penetrometer resistance with a $30^{\circ}$ cone penetrometer (Finlay Irvine Ltd, 140 Penicuik, Scotland) using the method described by USDA (1995). Two series of 141 readings were taken - one at the surface of the soil and the second $10 \mathrm{~cm}$ below the 142 surface. Ten readings were taken for each subplot and the mean computed. The 143 second method measured the porosity of the soil using thin-section microscopy. An 144 undisturbed sample $(5 \mathrm{~cm}$ depth) was taken from each subplot. Thin sections were 145 prepared using the method of Murphy (1986) with image capture (Coolview II, 146 Photonic Science Ltd., Mountfield, UK) and electronic image analysis (Image Pro 147 Plus, Media Cybernetics Inc., Silver Spring, USA)

148 Extraction of free living nematode stages used an adapted Baermann funnel 149 method (Hooper 1986). An approximate weight of $600 \mathrm{~g}$ of soil was sampled from the 150 top $2 \mathrm{~cm}$ of the soil surface from each subplot. Free moving nematodes were extracted 151 by soaking the soil sample for $12 \mathrm{~h}$ in water and allowing the nematodes to move into 152 the aqueous phase. The nematodes were extracted into $20 \mathrm{ml}$ of water and, after 153 thorough mixing, a count of motile nematodes was made on a $1 \mathrm{ml}$ sub-sample using 154 a $10 \times 10$ magnification.

\section{Statistical analysis}

156 Treatment differences were statistically compared using a randomised block analysis 157 of variance. The treatment sums of squares were orthogonally partitioned into three 158 specific pre-planned treatment comparisons (Steel and Torrie, 1960). All statements 
159 of significance are based on a probability of less than 0.05 . Statistical analysis was

160 performed using SPSS (1997) and GENSTAT software.

161

162 RESULTS

163 All the grass swards established successfully in each of the 4 soil media on each of the

164 three separate areas and there was complete grass cover on each of the subplots when

165 the wire cage protections were removed and the birds were given free access. There

166 were no visual differences in the condition or growth of the swards between the 4 soil

media. The monthly rainfall during the experimental period for October 2006 to

March 2006 was 80.4, 67.4, 38.8, 12.8, 27.2 and $54.0 \mathrm{~mm}$ respectively, compared to

the mean rainfall in the same month over the previous 10 years of $65.3,57.7,54.9$,

37.0, 42.2 and $39.5 \mathrm{~mm}$ respectively. Although there were monthly variations, the

total rainfall over the 6 -month period $(280.6 \mathrm{~mm})$ was similar to the mean 10 -year

average rainfall for these months $(296.6 \mathrm{~mm})$ at the research site.

There were statistically significant differences in the hens' preferences for

174 grass swards grown on the 4 soil media when the birds were first introduced to the 4

175 different swards (fenced areas) (Table 1). The birds spent a greater proportion

$176(P<0.01)$ of their time on the two topsoil swards in comparison to the two compost-

177 based swards. However, once the whole flock of hens had prolonged access to the

178 different swards (unfenced areas) there were no significant $(P>0.05)$ differences in the

179 number of birds that frequented the different sward types.

180 In common with the rest of the range area that was adjacent to the three main

181 plots, the grass sward gradually disappeared over the course of the 6-month period. At

182 the end of the 6-month period, no subplot still had any grass cover (Figure 1).

183 However, the rate of loss of grass from the subplots was greater $(P<0.001)$ with the

Formatted: Body Text, Left, Indent: First line: 0 pt, Adjust space between Latin and Asian text, Adjust space

between Asian text and numbers

Deleted: However, the soil below the sward of the two compost-based soil media did appear to be somewhat darker in colour. II 
184 two compost-based soil media and the rate of loss in the $100 \%$ compost soil was

185 greater $(P<0.05)$ than the $90 \%$ compost and $10 \%$ sand.

Results on the effect of the 4 soil media on soil structure and free-moving nematodes are presented in Table 2. Porosity values were generally satisfactory for

188 air and water movement and root development (Yilmaz et al, 2003). The 100\%

189 Compost had a very high porosity rating at a proportion of 0.423 (pores larger than

$1900.02 \mathrm{~mm}$ in diameter). The $100 \%$ compost had a greater $(P<0.05)$ porosity than the

191 other three soil media and with such a high porosity and organic matter content, a soil

192 that was weak to excavation would be expected. Penetrometer resistance values are

193 generally low to very low (Yilmaz et al, 2003). Although there were no $(P>0.05)$

194 differences at the surface, the penetrometer resistance at $10 \mathrm{~cm}$ was greater $(P<0.01)$

195 in the $90 \%$ compost $+10 \%$ sand treatment compared to the $100 \%$ compost soil

196 medium (Table 2). The two compost-based soil media had 33\% fewer $(P<0.05)$

197 nematodes per gram of dry soil compared to the two topsoil based media.

\section{DISCUSSION}

200 When birds were first introduced to the fenced areas they preferred to move to the topsoil swards in comparison to the swards grown on compost-based soils. The birds used in this experiment had had a long experience of ranging on grass grown on topsoil and evidently had an initial aversion to the recycled vegetable waste swards. Birds are known to use olfactory cues to locate and discriminate between foods (Wenzel and Sieck, 1972) and were apparently able to detect the difference between the two soil media types. However, the lack of differences in preferences in the unfenced areas, when the birds were allowed long-term access to the areas, indicated 
208 that these initial preferences were soon overcome and other cues to the birds' location

209 within the range dominated their preferences.

behavioural observation periods. This was a relatively high use of the plots by the

laying hens in comparison to adjacent parts of the range area. The three plots only

comprised approximately $0.2 \%$ of the total range area and not all birds made any use

of the range. Zeltner et al. (2004) observed a 3000 bird free-range flock and found

that only $19.5 \%$ of the birds used the range at all and over half of these never went away from the area immediately nearest to the fixed house.

The faster rate of loss of grass from the compost-based soils would be of great

218 practical significance to a commercial free-range egg producer who would want to

219 maintain a good grass cover on the range. There was no evidence that the birds

220 preferred the compost-based soil swards, but the faster rate of grass loss may have

221 been due to a poorer soil structure. The high porosity of the compost-based soils

222 indicates that the soil was more fragile and liable to break up under the feet of the

223 birds as seen in the grass cover results. The $90 \%$ compost and $10 \%$ sand treatment 224 gave a significant $(P<0.05)$ reduction in porosity. However porosity was still 225 satisfactory for air and water movement and root development (Yilmaz et al, 2003), 226 although it was not as high as the two topsoil treatments. The penetrometer results for $22710 \mathrm{~cm}$ depth are interpreted as showing that soil just below the surface provided better 228 support for the overlying soil aiding sward preservation. This indicates that particular 229 soil media formulations, that are based on compost, could be derived that have 230 suitable soil structure characteristics.

231 The nematode quantification technique measured total motile nematodes in the soil 232 and was not able to identify between species. However, it gives an indication of the 
233 probable poultry nematode worm infestation on the different swards. The mean size and number of nematodes was used to approximately calculate the motile nematode biomass and this indicated that it was approximately $400 \mathrm{mg}$ per $\mathrm{m}^{2}$ of soil media.

This is similar to the mean motile nematode biomass found in a survey of UK temporary grass swards (Cook et al., 1992). The part-sterilised topsoil had the numerically highest $(P>0.05)$ nematode population of the 4 soil media. The soil nematode sample was taken approximately 6 months after the soil media was

240 introduced and this indicates that nematodes are quickly able to repopulate an area.

241 The two compost-based soils had fewer $(P<0.05)$ nematodes than the topsoil-based

242 soils and this indicates that there are soil media that can slow the increase in nematode

243 populations in the range areas of laying hens. Only two rudimentary compost

244 formulations were used in this experiment, but it shows that the inclusion of a

245 proportion of composted vegetable waste could have significant long-term benefits to

246 the health status of free-range laying hen flocks. The results therefore indicate that

247 there may be potential to use compost to formulate soil media to reduce the nematode worm populations in the range areas for laying hens.

249 Acknowledgements

250 The authors acknowledge the support of the British Council and the National 251 Agricultural Research Foundation through the project "Improvement of the welfare of 252 free-range laying hens by innovative changes in range management". 
253

254

\section{References}

COOK, R., MIZEN, K.A., PLOWRIGHT, R.A. and YORK, P.A. (1992).

Observations on the incidence of plant parasitic nematodes in grasslnad in England and Wales. Grass and Forage Science, 47 : 274-279.

Formatted: Font: Italic

MARTIN, P.\& BATESON, P.P.F.(1993). Measuring Behaviour. An Introductory Guide. $2^{\text {nd }}$ Edition. Cambridge University Press, Cambridge.

MURPHY, C.P. (1986). Thin Section Preparation of Soils and Sediments 1. Soil Micromorphology. AB Academic Publishers, Berkhamstead, Herts, UK.

NOBLE, R. \& ROBERTS, S.J. (2004). Eradication of plant pathogens and nematodes during composting: a review. Plant Pathology, 53: 548-568.

PENNYCOTT, T.W. \& STEEL, F. (2001). Parasitic worms in commercial free-range poultry flocks in England and Wales. Veterinary Record, 149: 428.

PERMIN, A., BISGAARD, M., FRANDSEN, F., PEARMAN, M., KOLD, J. \& NANSEN, P. (1999). Prevalence of gastrointestinal helminths in different poultry production systems. British Poultry Science, 40: 439-443.

SPSS (1997). SPSS Base 7.5 for Windows, Chicago, IL, SPSS.

STEEL, R.G.D. \& TORRIE, J.H. (1960). Principles and Procedures of Statistics, $2^{\text {nd }}$ edn, New York, McGraw-Hill. 
278 USDA (1995). Soil Survey Manual. Handbook No. 18. National Resource

279 Conservation Service, Washington D.C.

280 USEPA (1997). Innovative uses of compost. Disease control for plants and animals.

281 EPA530-F07-044. United States Environmental Protection Agency (5306W).

282 Washington D.C.

283 WENZEL, B.M. \& SIECK, M.H. (1977). Olfactory perception and bulbar electrical

284 activity in several avian species. Physiology and Behaviour, 9: 287-293.

285 YILMAZ, K, N W HALL, N W, \& COŞCAN P K. (2003). An evaluation of soil

286 compaction in the Narli Plain irrigation area, Kahramanmaraş, eastern Turkey. Soil

287 Science, $1687,516-528$.

288 ZELTNER, E., HIRT, H. \& HAUSER, J. (2004). How to motivate laying hens to use 289

the hen run? Proceedings 2nd SAFO Workshop, Witzenhausen, Germany. Pp 161-165.

Formatted: Font: (Default) Times New Roman, Polish

Formatted: Font: (Default) Times New Roman, Italic, Polish

Formatted: Font: (Default) Times

New Roman, Polish 
1

2

3

4

5

6

7

8

9

Table 1. Hens' preferences for grass swards grown on the 4 soil media.

$\begin{array}{lcc}\text { Soil media } & \text { Enclosed area } & \text { Open area study }\end{array}$

study

(Proportion of Number of birds (from the time spent whole flock) standing on

standing on the subplot

treatment subplot)

(No. birds/h)

\begin{tabular}{lll}
\hline Composted vegetable waste & 0.175 & 6.44 \\
$90 \%$ Composted vegetable waste + & 0.135 & 6.86
\end{tabular}

$10 \%$ sand

$\begin{array}{lll}\text { Topsoil } & 0.288_{-}^{*} & 7.94\end{array}$

$\begin{array}{lll}\text { Sterilized topsoil } & 0.402_{-}^{*} & 5.58\end{array}$

$\begin{array}{lll}\mathrm{SED}^{1} \text { (6 degrees of freedom) } & 0.04547\end{array}$

$290 \mid$ * F Factors within the same coloumn that are significantly different at $P=0.05$ 
Table 2. Effect of the 4 soil media on soil structure and grass cover measurements.

Deleted: free-moving nematodes II

\begin{tabular}{|c|c|c|c|c|c|c|}
\hline \multicolumn{2}{|l|}{ Variable } & \multicolumn{2}{|c|}{ Soil media } & & & \\
\hline $\begin{array}{l}\text { Soil penetrometer resistance } \\
\text { (Cone index units) }\end{array}$ & $\begin{array}{c}\text { Composted } \\
\text { vegetable waste }\end{array}$ & $\begin{array}{l}90 \% \text { composted } \\
\text { vegetable waste } \\
10 \% \text { sand }\end{array}$ & Topsoil & $\begin{array}{l}\text { Sterilised } \\
\text { topsoil }\end{array}$ & $\begin{array}{l}\text { SED }^{1} \\
\text { (6 degrees of } \\
\text { freedom) }\end{array}$ & \\
\hline \multicolumn{7}{|l|}{ (Sampled in October 2005) } \\
\hline Surface & 18.0 & 24.1 & 23.9 & 27.1 & 5.62 & \\
\hline $10 \mathrm{~cm} /$ depth & 30.0 & $38.8 * *$ & 26.1 & 33.7 & 3.76 & \\
\hline \multicolumn{7}{|l|}{$\begin{array}{l}\text { Soil microscopy } \\
\text { (Sampled in October 2005) }\end{array}$} \\
\hline \multirow{2}{*}{$\begin{array}{l}\text { No. of pores per } 50 \mathrm{~mm}^{2} \\
\text { Porosity } \\
\text { (Proportion of soil as air for } \\
\text { pores greater than } 0.02 \mathrm{~mm} \\
\text { diameter) }\end{array}$} & 424 & 351 & 445 & 384 & 67.8 & \\
\hline & $0.423 *$ & 0.204 & 0.278 & 0.197 & 0.0204 & \\
\hline \multicolumn{7}{|l|}{$\begin{array}{l}\text { Soil nematode count } \\
\text { (Sampled in February 2006) }\end{array}$} \\
\hline $\begin{array}{l}\text { Water content of soil sample } \\
(\mathrm{g} / \mathrm{kg})\end{array}$ & 306 & 268 & 262 & 302 & 52.5 & \\
\hline $\begin{array}{l}\text { Nematode count per g of dry } \\
\text { matter }\end{array}$ & $13.8_{-}^{*}$ & $14.2 *$ & 18.6 & 23.5 & 3.93 & \\
\hline \multirow{2}{*}{\multicolumn{6}{|c|}{$\begin{array}{l}*=\text { Factors within the same row that are significantly different at } P=0.05 . \\
* *=\text { Factors within the same row that are significantly different at } P=0.01 \text {. } \\
\text { SED }^{1}=\text { Standard Errors of Differences of Means. }\end{array}$}} & \\
\hline & & & & & & Deleted: II \\
\hline
\end{tabular}


Figure 1. Proporion of grass cover on four soil media (vertical bars indicate SED (6df))



